\title{
Phonological development of children aged 3 to 7 under the condition of sentence repetition
}

\author{
Soo-Jin Kim ${ }^{1} \cdot$ Na rae Park ${ }^{1} \cdot$ Moon Soo Chang ${ }^{2} \cdot$ Young Tae Kim ${ }^{3} \cdot$ Moonja Shin ${ }^{4} \cdot \mathrm{Ji}-\mathrm{Wan} \mathrm{Ha}^{5, *}$ \\ ${ }^{1}$ Department of Communication Disorders, Korea Nazarene University, Cheonan, Korea \\ ${ }^{2}$ Department of Software, Seokyeong University, Seoul, Korea \\ ${ }^{3}$ Department of Communication Disorders, Ewha Womans University, Seoul, Korea \\ ${ }^{4}$ Department of Speech-Language Pathology, Chosun University, Gwangju, Korea \\ ${ }^{5}$ Department of Speech Pathology, Daegu University, Gyeongsan, Korea
}

\begin{abstract}
Sentence repetition is a way of evaluating speech sound production to improve the limitation of word tests and spontaneous speech analysis. Speech sounds produced by children can be evaluated using several indicators. This study examined the progression of the percentage of correct consonants-revised (PCC-R) and phonological whole-word measure in different age and gender groups after setting consonants in various vowel contexts and implementing sentence repetition tasks that were designed to give all phonemes the chance to appear at least three times. For this study, 11 sentence repetition tasks were applied to 535 children aged 3 to 7 across the country, after which the resulting PCC-R and whole-word measure were analyzed. The study results showed that all the indicators improved in older age groups and there were significant differences depending on age, however, no significant differences dependent on gender were found. The sentence repetition conditions data used in this study were collected from across the country, and the age difference between each age group was six months. This study is noteworthy because it collected a sufficient amount of data from each group, highlighted the limitation of the word naming and the spontaneous speech analysis, and suggests new criteria of evaluation through the analysis of each whole-word measure in sentence repetition, which was not applied in previous studies.
\end{abstract}

Keywords: speech sound disorders, sentence repetition, PCC-R, phonological whole-word measures, speech development

\section{1. 서론}

음운발달 검사에 가장 많이 사용되는 방법은 출판되어 있는 말소리 평가도구의 단어문맥에서 대상자의 말소리산출 능력을
평가하는 것이다. 그러나 단어문맥 검사는 말소리산출에 영향 을 미치는 다양한 요소들을 관찰하는데 어려움이 있으며, 어린 연령에도 천정점수에 이르는 등 제한적인 정보만을 제공한다. 따라서 아동의 말소리산출 능력을 보다 정확하게 평가하기 위

\footnotetext{
*jw-ha@daegu.ac.kr, Corresponding author

Received 3 February 2020; Revised 28 February 2020; Accepted 9 March 2020

(C) Copyright 2020 Korean Society of Speech Sciences. This is an Open-Access article distributed under the terms of the Creative Commons Attribution NonCommercial License (http://creativecommons.org/licenses/by-nc/4.0) which permits unrestricted non-commercial use, distribution, and reproduction in any medium, provided the original work is properly cited.
} 
해서는 자발화 또는 문장 따라말하기 등 다른 방법을 병행하는 것이 바람직하다. 이 중 가장 이상적이고 타당한 평가문맥은 일 상에서 산출하는 자발화일 것이다. 그러나 이 또한 평가 상황을 낯설어 하는 어린 아동에게는 부담스러운 과제일 수 있고 자발 화를 유도하는 검사자의 역량에 따라 그 결과가 달라질 수 있다 는 제한점을 가진다. 때문에 이에 대안으로 문장 따라말하기를 사용하기도 한다.

그런데 문장 따라말하기는 자발화의 대안책으로만 간주하기 에는, 단어뿐 아니라 자발화와 비교하여도, 다음과 같은 측면에 서 상당히 유용하다. 첫째, 문장 따라말하기는 단어수준 검사보 다 말소리장애 심각도에 대한 임상가들의 평정 결과와 상관이 높다(Bang, 2017). 둘째, 따라말하기 과제는 각 음소별로 다양한 문맥에서 여러 번의 산출 기회를 제공할 수 있기 때문에, 후행 모음의 영향, 내용형태소와 문법형태소의 차이 등 음소산출에 영향을 주는 요인을 함께 고려하는 것이 가능하다(DuBois, \& Bernthal, 1978; Johnson et al., 1980; Kim et al., 2012; Woo \& Kim, 2013). 즉, 자발화 검사의 장점으로 강조되었던 언어적 환경의 영향력을 문장 따라말하기 검사를 통해서도 살펴볼 수 있다. 셋 째, 자발화 또는 대화 과제에서는 대상자들이 어려운 발음은 기 피하고 선호하는 말소리 위주로 발화를 산출하여 모든 말소리 를 평가하지 못할 수 있다. 이에 반해 따라말하기로 발화를 유 도하면 짧은 시간 안에 다양한 조건에서 목표 말소리를 모두 산 출하도록 할 수 있다(Choi \& Kim, 2013; Kenney et al., 1984; Park $\& \mathrm{Kim}, 2015)$. 따라서 문장 따라말하기 과제를 적절하게 사용할 경우 아동의 말소리산출 능력을 간편하면서도 깊이 있게 평가 하는 것이 가능하다.

대상아동의 말소리가 또래 일반아동과 비교하여 적절하게 발달하고 있는지, 성인의 음운체계와 비교하여 어떤 차이를 보 이는지 등을 타당하고 정확하게 평가하기 위해서는 객관적인 측정치를 사용해야 한다(Ha \& Hwang, 2013). 단어수준 및 자발 화 검사와 마찬가지로, 문장 따라말하기 검사에서도 분절음 혹 은 단어단위 수준으로 말소리산출 능력을 분석하여 객관적인 측정결과를 도출해낸다. 그 지표로, 분절음단위 분석에는 자음 정확도(percentage of correct consonants: $\mathrm{PCC}$ ), 개정자음정확도 (percentage of correct consonants-revised: PCC-R), 명료도(speech intelligibility) 등을, 단어단위의 분석에는 단어단위 정확률 (proportion of whole-word correctness: PWC), 평균음운길이 (phonological mean length of utterance: PMLU), 단어단위 근접률 (proportion of whole-word proximity: PWP) 등을 들 수 있다(Kim $\&$ Shin, 2015).

자음정확도(PCC)는 Shriberg \& Kwiatkowski(1982)에 의해 그 분석방법이 제안된 이후, 말소리장애의 유무와 심각도를 결정 하는 데에 평가 현장에서 가장 널리 쓰이는 지표이다. 개발 당 시에는 자발화 등 문장수준에서 사용하도록 하였으나, 현재에 는 단어수준 검사에도 많이 적용된다. 이에 반해 단어단위 분석 은 언어발달 초기 아동의 경우 개별 분절음보다 단어단위 형태 로 언어 및 말소리 체계를 습득한다는 가정 하에 개발된 방법으 로, 자발화 또는 문장수준의 평가에 적절하다(Ingram, 2002;
Yoon et al., 2013). 이 중 단어단위 정확률(PWC)은 아동이 산출 한 전체 단어 중에서 정확하게 발음한 단어의 비율을 의미하고, 평균음운길이(PMLU)는 목표하는 단어의 복잡성을 보여주는 지표로 아동이 산출한 분절음 수와 정확하게 조음한 자음의 수 를 더하여 계산한다. 그리고 단어단위 근접률(PWP)은 아동이 목표 단어와 얼마나 유사하게 말소리를 산출하였는지 보여주 는 지표로, 성인이 산출한 PMLU와 아동이 산출한 PMLU의 비 율로 구한다. 이와 같은 단어단위 음운지표들은, 앞에서 설명하 였듯이, 개발 당시에는 자발화 문맥에서 초기 말소리발달을 평 가하기 위해 제안되었으나(Ingram, 2002), 최근 연구에서는 후 기 말소리발달을 민감하게 평가하는 데에도 유용한 지표임이 보고된 바 있다(Ha et al., 2019).

앞에서 언급하였듯이 자발화와 유사한 장점을 가지면서 단 어수준 검사처럼 제한된 시간 안에 다양한 음소를 평가할 수 있 기 때문에, 임상현장에서 말소리산출 지표를 분석할 때에도 문 장 따라말하기는 매우 유용한 과제이다. 이와 관련하여 $\mathrm{Kim}$ (2016)은 말소리장애를 선별할 수 있는 세 문장 따라말하기 검 사를 개발하였는데, 세 문장으로 이루어진 매우 간단한 방법임 에도 불구하고 민감도와 특이도 측면에서 기존 검사들과 유사 한 결과를 도출할 수 있다고 보고하였다. 그러나 국내의 말소리 산출 지표에 대한 연구는 단어수준 검사(Ha et al., 2019; Kim \& Seok, 2007; Park \& Seok, 2012; Park \& Son, 2012; Park et al., 2011; Seok, 2006)와 자발화 검사(Ha \& Hwang, 2013; Yoon et al., 2013)에서 연령에 따른 발달과 평가지표들 간 관계를 연구한 것 으로 국한되어 있고, 문장 따라말하기에서 말소리산출 지표에 대한 연구는 매우 제한적이다. 이러한 현 상황에서 우선적으로 마련되어야 하는 것은 문장 따라말하기 검사에서의 말소리 발 달규준이다. 다양한 지표에 대한 규준이 갖춰진다면, 문장 따라 말하기 검사를 이용하여 말소리산출 능력을 진단할 때 표준화 준거데이터로 유용하게 활용할 수 있을 것이다.

국내 말소리장애 진단평가에 사용되는 검사도구로는 우리말 조음-음운평가(Urimal-Test of Articulation and Phonology, UTAP; Kim \& Shin, 2004), 아동용발음평가(Assessment of Phonology and Articulation for Children, APAC; Kim et al., 2007), 한국어 표준 그림 조음음운검사(The Korean Standard Picture of Articulation and Phonological Test, KS-PAPT; Seok et al., 2008)가 있다. 이 검 사들은 모두 단어수준에서 $\mathrm{PCC}$ 에 대한 규준만을 제공할 뿐, 문 장수준에서는 어떠한 지표에 대해서도 규준을 제공하고 있지 않다. 또한 규준 데이터가 학령전기에 국한되어 있어, 학령기 아동의 평가로는 부적절하다. 음운발달에 대한 국내 연구들 또 한 $2,3,4$ 세 혹은 $3,4,5$ 세와 같은 세 연령 단위를 비교한 경우가 대부분이다. 뿐만 아니라 특정 지역에 국한하여 자료를 수집하 였으며, 대상자 수도 12 개월 단위로 한 연령 당 15 명에서 40 명 정도로 제한되어 있다(Ha \& Hwang, 2013; Kim et al., 2012; Park \& Seok, 2012; Park \& Son, 2012; Park \& Yoon, 2016; Seok, 2006; Yoon et al., 2013). 이와 같은 말소리장애 분야의 임상적 및 학술 적 현실을 반영하여, 새롭게 개발된 우리말조음음운평가2(Urimal Test of Articulation and Phonology, UTAP2; Kim et al., 2020)에서 
는 단어수준 검사와 더불어 문장 따라말하기 검사를 추가하였 다. 이에 본 연구에서는 새롭게 추가된 UTAP2의 문장수준 검사 에서 PCC-R, PWC, PMLU, PWP와 같은 다양한 말소리산출 지표 에 대한 연령집단별 차이를 살펴보고자 하였다.

말소리장애 진단 상황에서 평가 받는 아동의 문제와 그 정도 를 판단하는 중요한 기준은 연령이 같은 또래 일반아동의 발달 준거이다. 발달 준거의 정확성을 높이기 위해서는 우선적으로 연령별로 충분한 수의 아동이 다양한 지역에서 표집되어야 하 고, 이를 기반으로 할 때 비로소 진단의 타당성이 보장될 수 있 다. 따라서 본 연구에서는 문장수준에서 말소리발달이 활발하 게 이루어진다고 알려진 만 3세부터 7세의 아동들을 대상으로 실험을 진행하였다. 연령별로 전반과 후반으로 나누어 연령집 단을 세밀하게 구분하고 각 집단별 인원도 50 명 내외를 목표로 하여, 한국 아동의 문장수준 발화에 대해 대표성을 갖춘 말소리 발달 이정표를 제시하고자 하였다.

\section{2. 연구방법}

\section{1. 연구참여자}

서울경기, 충청도, 경상도, 전라도의 각 지역의 대표연구자 1 인이 독자적으로 $4 \sim 10$ 인으로 구성된 연구팀을 구성하였다. 언 어병리학과 또는 언어치료학과 교수, 대학원생 등으로 구성된 각 연구팀은 서울, 경기, 충청, 경상, 전라, 제주의 국내 전역에 서 3 세부터 7세까지의 아동들을 모집하였다. 본 연구에 참여한 전체 대상자는 3세 전반부터 7세 후반까지 총 535명이었는데, 이는 Ha et al.(2019), Shin et al.(2019)의 연구에서 3세부터 7세에 해당하는 연구대상자들과 동일한 아동들이다. 이들은 수용 - 표 현어휘력검사(Receptive \& Expressive Vocabulary Test, REVT; Kim et al., 2009)에서 수용어휘력이 2\%ile 이상이고, 문장수준의 검사수행이 어려울 정도의 어떤 문제도 동반하고 있지 않고, 일 반 어린이집, 유치원 및 학교에 다니는 아동들이었다. 선정된 아동이라도 검사 과정에서 주어진 지침대로 문장을 따라말하 는 것에 어려움을 보이면 대상에서 제외하였다. 아동의 보호자 또는 담당 교사는 대상아동이 본 실험에 참여하는 것을 모두 동 의하였다. 본 연구에 최종적으로 포함된 집단별 대상자 인원과 수용어휘 원점수는 표 1 과 같다.
표 1. 참여자 집단의 연령, 성별 및 수용어휘 점수 Table 1. Age, gender, and receptive vocabulary score of participants

\begin{tabular}{l|c|c|c|c}
\hline Age $(\mathrm{yr} ; \mathrm{mo})$ & Boy & Girl & Total & $\begin{array}{c}\text { REVT-R } \\
\text { M }(S D)\end{array}$ \\
\hline $3 ; 0 \sim 3 ; 5$ & 17 & 25 & 42 & $28.21(10.32)$ \\
\hline $3 ; 6 \sim 3 ; 11$ & 28 & 28 & 56 & $32.95(10.96)$ \\
\hline $4 ; 0 \sim 4 ; 5$ & 39 & 40 & 79 & $43.42(12.84)$ \\
\hline $4 ; 6 \sim 4 ; 11$ & 38 & 36 & 74 & $49.59(11.08)$ \\
\hline $5 ; 0 \sim 5 ; 5$ & 29 & 38 & 67 & $56.60(12.51)$ \\
\hline $5 ; 6 \sim 5 ; 11$ & 33 & 38 & 71 & $64.60(9.47)$ \\
\hline $6 ; 0 \sim 6 ; 5$ & 29 & 38 & 67 & $68.49(10.65)$ \\
\hline $6 ; 6 \sim 6 ; 11$ & 18 & 15 & 33 & $78.64(10.76)$ \\
\hline $7 ; 0 \sim 7 ; 5$ & 19 & 14 & 33 & $85.42(11.72)$ \\
\hline $7 ; 6 \sim 7 ; 11$ & 6 & 7 & 13 & $95.77(12.92)$ \\
\hline Total & 256 & 279 & 535 & \\
\hline
\end{tabular}

REVT, Receptive \& Expressive Vocabulary Test.

\section{2. 도구: 문장 따라말하기 과제}

우리말 조음-음운평가2(UTAP2, Kim et al., 2020)의 문장수준 검사 자료를 사용하였다. 문장수준 검사 과제는 연습문항 1 문 항을 포함해 총 12 문장으로 각 문장은 4 5어절로 구성되어있 다. 문장수준 검사 문항은 부록 1 과 같다. 11 개의 검사 문장에서 18 개의 초성 자음은 세 번 이상 산출되는데, 세 가지 이상의 다 른 모음과 결합되도록 제작되었고, 어중의 6 개 종성과 7 개의 어 말종성도 모두 산출될 수 있도록 개발되었다. 아동들은 각 검사 문장에 해당하는 장면 그림을 보면서, 검사자가 제시하는 자극 문장을 그대로 따라말하게 된다.

2.3. 절차

\subsection{1. 검사 진행}

각 연구팀의 연구원들은 실험에 참여하기 전 2 차례 이상의 검사자 훈련을 의무적으로 받았다. 1 차 훈련은 검사내용 및 실 시방법에 대한 강의로 이루어졌고, 2 차 훈련은 실제로 검사를 실시해본 후 이에 대한 피드백을 받는 방식으로 진행되었다. 이 후 필요에 따라 3 차 이후의 훈련이 추가적으로 실시되었다.

검사는 아동의 어린이집, 유치원, 학교, 가정을 방문하여 조 용하고 개별적인 공간에서 진행하였다. 검사 진행에 앞서 보호 자 혹은 교사에게 아동의 생년월일, 장애 유무 등의 특이 사항 에 관한 배경정보를 구하였다. 그러고 나서 REVT의 수용어휘 력검사를 실시한 후 문장 따라말하기 과제를 실시하였다. 아동 에게 한 문장 당 문장 내용을 반영하는 한 장의 그림자극을 보 여주면서, 검사자가 전체 문장을 1 회 들려주고 따라 말하도록 유도하였다. 아동이 전체 문장을 따라 말하지 못했을 경우 2어 절씩 끊어서 들려주었다. 이때에도 적절한 반응을 하지 못한 경 우는 분석에서 제외하였고, 이에 맞춰 목표 어절수를 조정하였 다. 검사는 아동의 반응을 기록지에 기록하였고 녹음기로 녹음 하여 전사하고 한국어말소리평가프로그램 전산화 자동분석 프 로그램(Korean Speech Sound Analysis Tool, KSAT; Kim et al., 2016)에 입력한 후 분석하였다. 


\subsection{2. 자료 평가}

문장의 특성이 자발화와 유사한 특성을 갖고 있으므로 자발 화에서 말소리 지표를 분석하는 방법과 같은 절차로 PCC-R과 음운지표 값을 분석하였다. 문장발화에서 왜곡반응을 정확하 게 분석하는 것은 쉽지 않은 작업일 뿐 아니라, 정상성인도 긴 발화를 빠른 속도로 발음할 경우 목표음소에 근접한 왜곡산출 이 빈번하게 관찰된다. 때문에 본 연구에서는 왜곡을 오류에 포 함시킨 PCC 대신 정조음으로 간주한 PCC-R 값만을 구하였다. 음운지표 값 분석 시에는 우선적으로 단어경계를 구분해야 한 다. 한국어에서 조사는 다른 단어와 결합하여 한숨에 발음되는 데, 조사를 독립적으로 분류하는 문법 단어의 기준을 따라 경계 를 구분할 경우 현실적인 발음형과 차이가 생긴다. 이러한 이유 로 한국어 자발화 분석 시 영어와 달리 어절 단위로 경계를 분 석하는 것이 타당하다는 선행연구(Yoon et al., 2013)에 근거하 여, 본 연구에서도 단어 대신 어절을 그 경계로 하였다. 그 밖에 구체적인 평가치 산출절차는 Kim \& Shin(2015)을 따랐다.

2.3.2.1. 개정자음정확도(Percentage of Correct Consonants: Revised) PCC-R은 자음을 정확하게 발음한 백분율로 자음이 생략되 거나 대치된 것만 오류로 보고 정조음한 자음의 비율을 구한다.

\section{$P C C-R=($ 정조음한 자음수 $/$ 조음해야 할 총 자음수 $) \times 100$}

2.3.2.2. 단어단위 정확률(Proportion of Whole-word Correctness: PWC)

$\mathrm{PWC}$ 는 성인의 표준 발음 전사와 일치한 어절을 정반응으로 하고 전체 어절에서 정반응 비율을 구한다. 정확률과 복잡률에 서 심한 왜곡은 오류로 보았으며, 미묘한 왜곡과 방언은 정반응 으로 간주하였다.

\section{$P W C=$ 정확하게 산출한 어절 수/전체 어절 수}

2.3.2.3. 단어단위 복잡률(Phonological Mean Length of Utterance: PMLU, 평균음운길이)

PMLU는 아동이 산출한 단어의 음운적 복잡성에 대한 정보 를 제공한다. 모든 분절음에 각 1 점씩을 제공한 후, 정조음한 자 음에 대해서는 추가로 1 점을 부여한다. 분절음에는 자음, 단모 음, 반모음이 포함되기 때문에, 이중모음의 경우 우선적으로 2 점이 제공된다. 이렇게 구한 복잡성 점수를 전체 어절 수로 나 누어서 구한다.

\section{$P M L U=$ 분절음수 정조음한 자음수/전체 어절 수}

2.3.2.4. 단어단위 근접률(Proportion of Whole-word Proximity: PWP) $\mathrm{PWP}$ 는 성인의 표준 발음을 목표로 하여 아동의 단어가 얼마 나근접했는가를 분석하기 위해 측정된다.
2.4. 분석

\subsection{1. 신뢰도 분석}

전체 자료에서 연령별로 약 $10 \%$ 씩, 총 55 명의 자료를 무작위 로 선정하여 전사자 간 신뢰도를 구하였다. 제 1 전사자는 각 대 상아동의 검사를 담당하였던 연구원이었고, 제 2 전사자는 본 연구의 저자 1 인이었다. 제 1 전사자와 제 2 전사자는 검사현장 에서 아동의 반응을 직접 기록하거나 검사 이후 녹음 파일을 반 복 재생하여 들으면서 전사하였다. 두 전사자 간 전사가 일치한 어절 수를 전체 목표 어절 수로 나눈 후 100 을 곱하여 일치도를 구하였다. 그 결과 전사자 간 평균 일치도는 $94.6 \%$ 였다.

\subsection{2. 통계 분석}

연령집단과 성별에 따른 각 지표에 대한 기술통계를 실시하 였으며, 각 지표별 연령집단과 성별에 따른 차이와 상호작용 효 과를 알아보기 위해 이원분산분석(two-way ANOVA)과 사후검 정으로 Duncan test를 실시하였다.

\section{3. 결과}

\section{1. 개정자음정확도(PCC-R) 발달}

연령별 성별 PCC-R의 기술통계표는 표 2 와 같다. 3 세 전반부 터 7세 후반까지 PCC-R은 그림 1과 같이 지속적으로 상승하는 것으로 나타났다. PCC-R 값이 높아지면서 집단내 표준편차가 줄어드는 것도 관찰할 수 있다. 각 집단 안에서 남아와 여아의 PCC-R은 연령이 증가할수록 평균은 유사하게 상승하고, 표준 편차의 범위가 줄어들었다. 그러나 5 세 후반 남아의 표준편차 는 4세 집단의 것과 유사한 반면, 5 세 후반의 여아의 표준편차 는 6 세 집단의 것과 유사하였다. 즉, 5 세 후반에 들어서면서 여 아의 PCC-R은 남아보다 평균적으로 다소 높고 표준편차도 줄 어들어, 높고 동질적인 PCC-R 점수대로 남아 집단보다 여아 집 단이 먼저 진입함을 알 수 있다.

분산분석 결과 연령별 차이 $(F=27.262, p<.001)$ 는 유의하였으 며, 성별차이 $(F=.118, p>.05)$ 와 연령과 성별의 상호작용효과 $(F=.600, p>.05)$ 는 유의한 차이가 없었다. 연령별 차이에 대한 사후검정 결과 3 세 초반은 이후 모든 집단과, 3 세 후반은 4 세 후 반 이후 모든 집단과, 4 세 초반과 4세 후반은 5 세 후반 이후 모 든 집단과, 5 세 초반은 6 세 초반 이후 모든 집단과 유의한 차이 가 있었고 $(p<.05), 5$ 세 후반 이후부터는 연령 간 차이가 유의하 지 않았다( $p>05)$. 이러한 결과를 바탕으로 동질적으로 분류된 하위집단들(sub groups)을 표 2에 제시하였다.

$P W P=$ 아동의 $P M L U /$ 목표발화 $P M L U$ 
표 2. 연령 및 성별 PCC-R 기술통계표

Table 2. Descriptive statistic results of PCC-R by age and gender

\begin{tabular}{l|c|c|c}
\hline Age $(\mathrm{yr} ; \mathrm{mo})$ & Boy $M(S D)$ & Girl $M(S D)$ & Sub group $^{*}$ \\
\hline $3 ; 0 \sim 3 ; 5$ & $79.0(13.0)$ & $76.5(15.7)$ & 1 \\
\hline $3 ; 6 \sim 3 ; 11$ & $87.5(12.4)$ & $85.9(12.6)$ & 2 \\
\hline $4 ; 0 \sim 4 ; 5$ & $89.0(8.3)$ & $91.7(7.2)$ & 2,3 \\
\hline $4 ; 6 \sim 4 ; 11$ & $90.4(9.6)$ & $91.3(10.1)$ & 3 \\
\hline $5 ; 0 \sim 5 ; 5$ & $94.2(9.2)$ & $93.5(9.9)$ & 3,4 \\
\hline $5 ; 6 \sim 5 ; 11$ & $95.1(9.5)$ & $98.2(3.8)$ & 4,5 \\
\hline $6 ; 0 \sim 6 ; 5$ & $97.1(2.5)$ & $98.2(3.1)$ & 5 \\
\hline $6 ; 6 \sim 6 ; 11$ & $98.0(3.2)$ & $99.4(0.6)$ & 5 \\
\hline $7 ; 0 \sim 7 ; 5$ & $99.7(0.5)$ & $99.3(0.6)$ & 5 \\
\hline $7 ; 6 \sim 7 ; 11$ & $100(0.0)$ & $99.9(0.2)$ & 5 \\
\hline${ }^{*}$ homogeneous sub group by post-hoc test (Duncan). \\
PCC-R, percentage of correct consonants-revised.
\end{tabular}

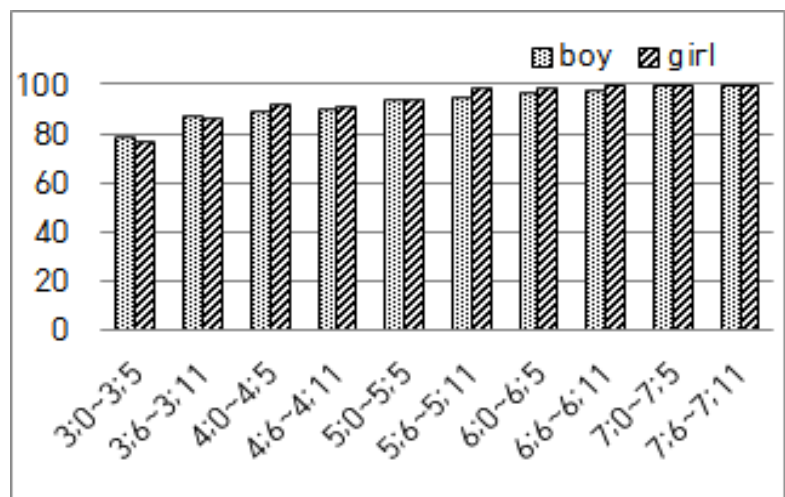

PCC-R, percentage of correct consonants-revised.

그림 1. 연령별 성별 개정자음정확도

Figure 1. PCC-R by age and gender

\section{2. 단어단위 정확률(PWC)의 발달}

연령별 성별 $\mathrm{PWC}$ 의 기술통계표는 표 3과 같다. 그림 2에서 알 수 있듯이 PWC는 3세 전반부터 6세 후반까지 지속적으로 상 승하였다. PWC의 평균과 표준편차는 PCC-R과 유사한 양상을 보였다. 각 집단 안에서 남아와 여아의 정확률은 연령이 증가할 수록 상승하였고, 표준편차의 범위는 줄어들었다. 표준편차의 경우 5 세 후반 남아 집단은 4 세 집단의 것과 유사한 반면, 5 세 후반 여아 집단은 6세 집단의 것과 유사하였다. 즉, PCC-R과 마 찬가지로 높고 동질적인 $\mathrm{PWC}$ 점수대로 남아 집단보다 여아 집 단이 먼저 진입하였다. 앞에서 살펴보았듯이 PCC-R은 가장 어 린 연령대인 3 세 초반에 이미 $70 \%$ 후반에 도달하여 점차적으로 상승하는데 비해, $\mathrm{PWC}$ 는 3 세 초반 $40 \%(0.4)$ 대에서 시작하여 3 , 4,5 세를 지나면서 매우 가파르게 상승하였다.

분산분석 결과 연령별 차이 $(F=32.279, p<.001)$ 는 유의하였으 며, 성별차이 $(F=.650, p>.05)$ 와 연령과 성별의 상호작용효과 $(F=.492, p>.05)$ 는 유의한 차이가 없었다. 연령별 차이에 대한 사후검정 결과 3 세 초반은 이후 모든 집단과, 3 세 후반, 4 세 초 반 및 4 세 후반은 5 세 초반 이후 모든 집단과, 5 세 초반은 6 세 초 반 이후 모든 집단과 유의한 차이가 있었고 $(p<.05), 5$ 세 후반 이 후부터는 연령 간 차이가 유의하지 않았다 $(p>.05)$. 이러한 결과 를 바탕으로 동질적으로 분류된 하위집단들(sub groups)을 표 3
에 제시하였다.

표 3. 연령 및 성별 $\mathrm{PWC}$ 기술통계표

Table 3. Descriptive statistic results of PWC by age and gender

\begin{tabular}{l|c|c|c}
\hline Age (yr;mo) & Boy $M(S D)$ & Girl $M(S D)$ & Sub group $^{*}$ \\
\hline $3 ; 0 \sim 3 ; 5$ & $0.47(.24)$ & $0.46(.29)$ & 1 \\
\hline $3 ; 6 \sim 3 ; 11$ & $0.68(.25)$ & $0.63(.26)$ & 2 \\
\hline $4 ; 0 \sim 4 ; 5$ & $0.68(.21)$ & $0.65(.19)$ & 2 \\
\hline $4 ; 6 \sim 4 ; 11$ & $0.72(.24)$ & $0.75(.25)$ & 2 \\
\hline $5 ; 0 \sim 5 ; 5$ & $0.83(.20)$ & $0.82(.24)$ & 3 \\
\hline $5 ; 6 \sim 5 ; 11$ & $0.87(.22)$ & $0.94(.10)$ & 3,4 \\
\hline $6 ; 0 \sim 6 ; 5$ & $0.93(.09)$ & $0.94(.11)$ & 4 \\
\hline $6 ; 6 \sim 6 ; 11$ & $0.93(.11)$ & $0.98(.03)$ & 4 \\
\hline $7 ; 0 \sim 7 ; 5$ & $0.99(.02)$ & $0.98(.02)$ & 4 \\
\hline $7 ; 6 \sim 7 ; 11$ & $1(.01)$ & $1(.01)$ & 4 \\
\hline
\end{tabular}

${ }^{*}$ homogeneous sub group by post-hoc test (Duncan).

PWC, proportion of whole-word correctness.

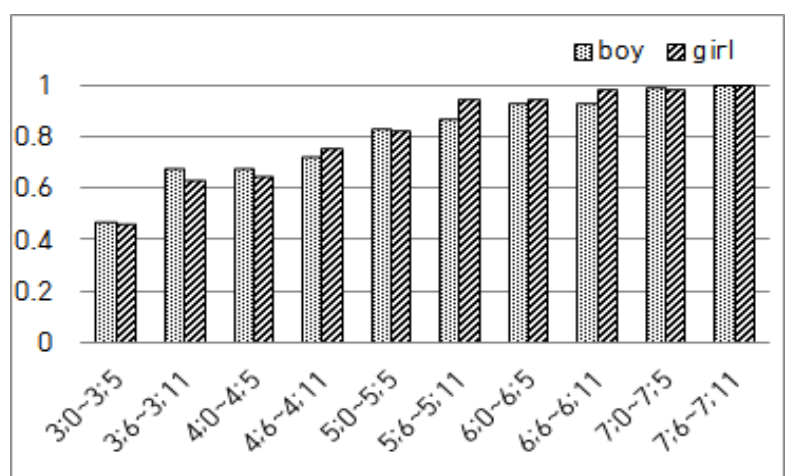

PWC, proportion of whole-word correctness.

그림 2. 연령별 성별 단어단위 정확률

Figure 2. PWC by age and gender

3.3. 평균음운길이(PMLU)의 발달

연령별 성별 PMLU의 기술통계표는 표 4 와 같다. 본 연구에 서는 목표 발화가 정해져 있는 따라말하기 과제를 사용하였기 때문에, 자발화 분석과 달리 PMLU에서도 점수의 최고치(10.89) 가 제한되어 있다. 그림 3을 살펴보면 평균 PMLU 값은 3세 전 반부터 7세 전반까지 지속적으로 상승하였고, 여아는 5세 후반 부터, 남아는 6세 후반과 7세 초반에 이르러 최고점수에 접근하 였다. 또한 PCC-R과 PWC와 마찬가지로 여아 집단은 5세 후반 부터 표준편차가 급격하게 줄어들어, 남아 집단보다 먼저 집단 내 개인차가 줄고 안정적인 양상을 보임을 알 수 있다.

분산분석 결과 연령별 차이 $(F=27.012, p<.001)$ 는 유의하였으 며, 성별차이 $(F=.467, p>.05)$ 와 연령과 성별의 상호작용효과 $(F=.501, p>.05)$ 는 유의한 차이가 없었다. 연령별 차이에 대한 사후검정 결과 3 세 초반은 이후 모든 집단과, 3 세 후반은 이후 모든 집단과, 4 세 초반과 4세 후반은 5 세 후반 이후 모든 집단과, 5 세 초반은 6세 초반 이후 모든 집단과 유의한 차이가 있었고 $(p<.05), 5$ 세 후반 이후부터는 연령 간 차이가 유의하지 않았다 $(p>.05)$. 이와 같은 결과를 바탕으로 동질적으로 분류된 하위집 단들(sub groups)을 표 4에 제시하였다. 
표 4. 연령 및 성별 평균음운길이 기술통계표

Table 4. Descriptive statistic results of PMLU by age and gender

\begin{tabular}{l|c|c|c}
\hline Age (yr;mo) & Boy $M(S D)$ & Girl $M(S D)$ & Sub group $^{*}$ \\
\hline $3 ; 0 \sim 3 ; 5$ & $9.67(.84)$ & $9.56(.98)$ & 1 \\
\hline $3 ; 6 \sim 3 ; 11$ & $10.15(.70)$ & $10.12(.66)$ & 2 \\
\hline $4 ; 0 \sim 4 ; 5$ & $10.27(.52)$ & $10.44(.41)$ & 3 \\
\hline $4 ; 6 \sim 4 ; 11$ & $10.33(.59)$ & $10.42(.57)$ & 3 \\
\hline $5 ; 0 \sim 5 ; 5$ & $10.57(.51)$ & $10.54(.52)$ & 3,4 \\
\hline $5 ; 6 \sim 5 ; 11$ & $10.63(.53)$ & $10.81(.21)$ & 4,5 \\
\hline $6 ; 0 \sim 6 ; 5$ & $10.73(.12)$ & $10.80(.14)$ & 5 \\
\hline $6 ; 6 \sim 6 ; 11$ & $10.77(.21)$ & $10.86(.03)$ & 5 \\
\hline $7 ; 0 \sim 7 ; 5$ & $10.87(.03)$ & $10.86(.03)$ & 5 \\
\hline $7 ; 6 \sim 7 ; 11$ & $10.88(.02)$ & $10.89(.01)$ & 5 \\
\hline
\end{tabular}

* homogeneous sub group by post-hoc test (Duncan).

PMLU, phonological mean length of utterance.

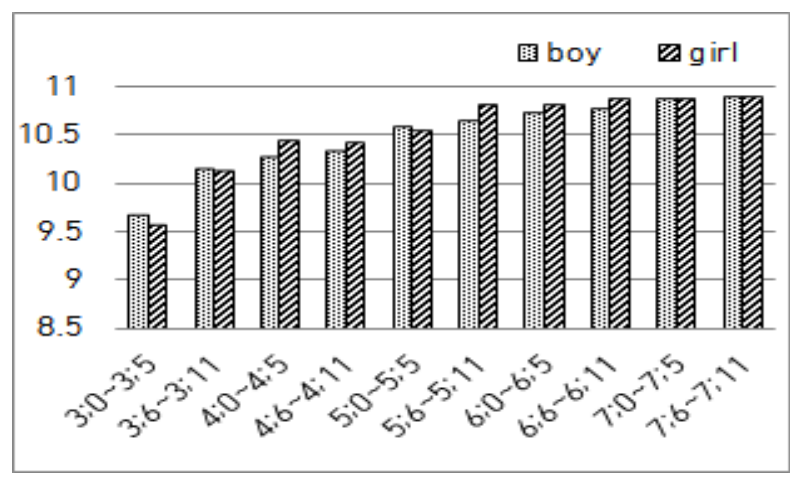

PMLU, phonological mean length of utterance.

그림 3. 연령별 성별 평균음운길이

Figure 3. PMLU by age and gender

3.4. 단어단위 근접률(PWP)의 발달

연령별, 성별 PWP의 기술통계는 표 5와 같다. 그림 4에서 알 수 있듯이 PWP는 3세 전반부터 6세 후반까지 지속적으로 상승 하여, 5 세 후반 경 최고점수인 1에 가까워졌다. 또한 다른 지표 들과 마찬가지로 여아 집단은 5 세 후반부터 표준편차가 줄어들 어, 남아 집단보다 먼저 집단 내 개인차가 줄고 안정적 양상을 보임을 알 수 있다.

분산분석 결과 연령별 차이 $(F=25,658, p<.001)$ 는 유의하였으 며, 성별차이 $(F=.687, p>.05)$ 와 연령과 성별의 상호작용효과 $(F=.402, p>.05)$ 는 유의한 차이가 없었다. 연령별 차이에 대한 사후검정 결과 3 세 초반은 이후 모든 집단과, 3 세 후반은 5 세 초 반 이후 모든 집단과, 4 세 초반과 4 세 후반은 5 세 후반 이후 모 든 집단과, 5 세 초반은 6 세 초반 이후 모든 집단과 유의한 차이 가 있었고 $(p<.05), 5$ 세 후반 이후부터는 연령 간 차이가 유의하 지 않았다( $p>.05)$. 이러한 결과를 바탕으로 동질적으로 분류된 하위집단들(sub groups)을 표 5에 제시하였다.
표 5. 연령 및 성별 PWP 기술통계표

Table 5. Descriptive statistic results of PWP by age and gender

\begin{tabular}{l|c|c|c}
\hline Age (yr;mo) & Boy $M(S D)$ & Girl $M(S D)$ & Sub group $^{*}$ \\
\hline $3 ; 0 \sim 3 ; 5$ & $0.89(.07)$ & $0.89(.08)$ & 1 \\
\hline $3 ; 6 \sim 3 ; 11$ & $0.94(.07)$ & $0.93(.06)$ & 2 \\
\hline $4 ; 0 \sim 4 ; 5$ & $0.94(.05)$ & $0.96(.04)$ & 2,3 \\
\hline $4 ; 6 \sim 4 ; 11$ & $0.95(.05)$ & $0.96(.05)$ & 2,3 \\
\hline $5 ; 0 \sim 5 ; 5$ & $0.97(.05)$ & $0.97(.05)$ & 3,4 \\
\hline $5 ; 6 \sim 5 ; 11$ & $0.98(.05)$ & $0.99(.02)$ & 4,5 \\
\hline $6 ; 0 \sim 6 ; 5$ & $0.99(.01)$ & $0.99(.01)$ & 5 \\
\hline $6 ; 6 \sim 6 ; 11$ & $0.99(.02)$ & $1(0)$ & 5 \\
\hline $7 ; 0 \sim 7 ; 5$ & $1(0)$ & $1(0)$ & 5 \\
\hline $7 ; 6 \sim 7 ; 11$ & $1(0)$ & $1(0)$ & 5 \\
\hline
\end{tabular}

${ }^{*}$ homogeneous sub group by post-hoc test (Duncan).

PWP, proportion of whole-word proximity.

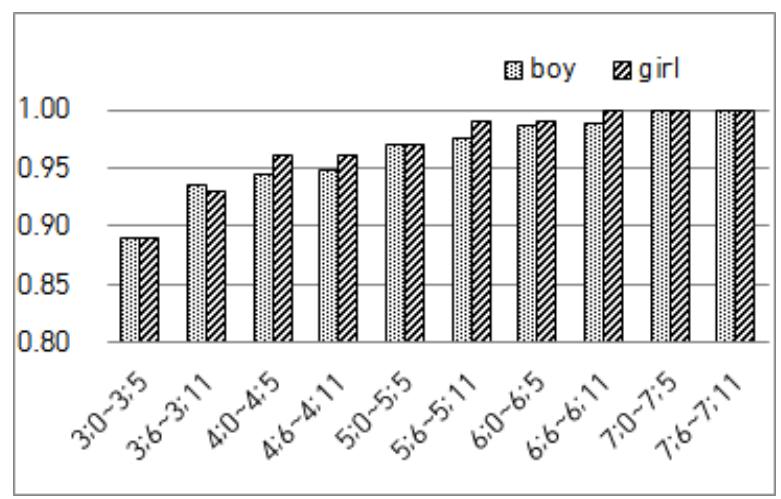

PWP, proportion of whole-word proximity.

그림 4. 연령별 성별 단어단위 근접률

Figure 4. PWP by age and gender.

\section{4. 논의}

국내에서 아동의 말소리발달을 살펴본 기존 연구들과 본 연 구의 차별점은 첫째, 전국적으로 충분한 수의 아동을 대상으로 하였고, 둘째, 3 세부터 7세까지 6 개월을 단위로 하여 10 개 집단 으로 나누었고, 셋째, 문장 따라말하기를 통해 발화자료를 수집 하였다는 데에 있다.

연구 결과 모든 음운지표는 3세부터 6세 혹은 7세까지 지속 적으로 향상되는 것으로 나타났다. 이 가운데 우선 임상 현장에 서 가장 많이 사용되는 $\mathrm{PCC}$ 에 대해 단어수준에서 분석한 기존 연구들과 비교해보면, Kim et al.(2005)의 결과에서는 3세 전반 에 $87 \%$, 4세 전반에 $95 \%$ 인데 반해 본 연구에서는 3 세 전반 $78 \%, 4$ 세 전반 $90 \%$ 를 보여서 큰 차이를 보였지만, 5 세 이후에는 유사한 것으로 나타났다. 그러나 본 연구와 동일한 아동들을 대 상으로 단어수준에서 PCC를 분석한 Ha et al.(2019)에서는 3세 전반에 $77 \%, 4$ 세 전반에 $91 \%$ 로 본 연구결과와 거의 차이가 없 었다. 그리고 본 연구와 동일한 대상자들에 대해 단어 수준에서 지역간 발달 차이를 살펴본 Shin et al.(2019)의 경우 2세와 3세 에는 서울경기와 기타 지역의 수행 차이가 유의한 수준으로 나 타나다가, 4세 이후에는 통계적으로 유의미한 차이가 없었다. 이러한 선행연구들을 종합하여 고찰해볼 때, 본 연구와 $\mathrm{Kim}$ et 
al.(2005)의 결과 간 차이는 단어와 문장이라는 문맥에 기인한 것이라기보다 서울경기지역 아동만을 대상으로 하였는지 아니 면 전 지역의 아동들을 포함하였는지의 지역적 차이 측면에서 해석할 수 있을 것이다.

동일한 대상자들에 대해 단어수준에서 음운발달을 살펴본 $\mathrm{Ha}$ et al.(2019)에서 PCC는 5세 전반에 천정점수에 도달하였고 사후검정에서 5 세 전반 이후 집단들 간에는 유의미한 차이가 나타나지 않았다. 그러나 문장수준에서 살펴본 본 연구결과에 서는 5세 후반에 이르러 PCC-R이 남아 $95 \%$, 여아 $98 \%$ 에 도달 하였고, 그 이후 연령집단들 간에는 유의한 차이를 보이지 않았 다. 통계적으로 남녀 성별차이는 유의하지 않았지만, 흥미로운 점은 5 세 후반 남아의 경우 PCC-R 평균(95.1\%)은 5 세 전반 아동 들과, 표준편차(9.5)는 4세 후반 아동들과 유사한 반면, 5 세 후반 여아는 평균과 표준편차 $(98.2 \%, 3.8 \%)$ 모두 6세 전반 아동들과 유사하였다. 5세 후반에 들어서면서 여아의 PCC-R이 남아보다 평균적으로 다소 높고 표준편차가 줄어드는 양상은 여아 집단 이 남아 집단보다 먼저 높고 집단 내 개인차가 줄어들어 안정적 인 PCC-R 점수대로 진입하고 있음을 시사한다. 이러한 양상은 PWC, PMLU, PWP의 다른 지표에서도 관찰되었으며, 이는 학 령전기 말소리발달에 있어 일반인들이 지각적으로 미묘하게 여아의 수행이 남아보다 좋다고 느끼는 것이 기술통계에 반영 되고 있는 것으로 보인다.

단어단위 평가지표인 PWC, PMLU, PWP의 모든 지표에서 연 령이 증가함에 따라 수치가 증가하였다. 자발화나 문장수준에 서 가장 간편하게 평가할 수 있는 PWC의 경우, 3 세 전반에 $78 \%$ 에 도달하였던 PCC-R에 비해 .47(47\%)로 매우 낮았다. 그러나 전반적인 상승세는 PCC-R보다 매우 가파르게 나타나, 대략적 으로 3 세 평균 $.50,4$ 세 평균 $.70,5$ 세 평균 $.80,6$ 세 이후 .95 를 보 였다. 이는 PWC가 전반적인 명료도와 용인도 등 일반인이 지각 하는 명료한 말의 발달 수준을 잘 반영하는 지표임을 보여주는 결과이다. 3 4세의 자발화에서 PWC를 분석한 Ha \& Hwang (2013)과 Yoon et al.(2013)에서는 본 연구결과보다 수치가 높았 다. 이는 자발화의 경우 아동이 본인에게 쉬운 말 위주로 발화 를 구성할 수 있는 반면, 본 연구에서는 미리 고안된 문장을 따 라 말하도록 하였기 때문에 정확하게 발음한 자음과 어절의 비 율이 낮아진 것으로 해석된다. 이에 반해 5 7세 아동을 대상으 로 단어수준에서 PWC를 분석한 Park \& Son(2012)의 결과에서 는 5세 .78, 6세 .82, 7세 .84로 본 연구보다도 그 수치가 더 낮았 다. 이유는 정확히 알 수 없지만, 채점과 분석과정에서 그 차이 가 초래되었을 가능성을 생각해볼 수 있다. 본 연구에서는 단어 단위 음운지표를 채점하는데 있어 음소 경계를 벗어난 심한 왜 곡은 오류로 보았지만 미세한 오류는 정반응에 포함하였고, 특 히 방언을 오류로 채점하지 않았다. 이러한 분석 상의 특성으로 인해 선행연구와 동일하지 않은 결과가 나타날 수 있을 것이다.

동일 대상 아동의 단어수준에서 $\mathrm{PWC}$ 를 살펴본 $\mathrm{Ha}$ et al. (2019)에서는 5세 후반에 남아는 .93, 여아는 .96이었고 6세 초반 에는 여아와 남아 모두 .98 이상으로 천점정수에 도달하였다. 반면 문장수준에서 살펴본 본 연구결과에서는 6세 후반(남아
.93, 여아 .98)이 되어서야 단어의 5 세 후반과 유사한 수준에 도 달하였고, 7세가 되어서야 천정점수에 도달하였다. PCC-R에서 처럼 남녀 성별차이는 유의하지 않았으나, 6세 후반 남아의 PWC 평균과 표준편차(.93, .11)는 6세 전반과 유사한 반면 6세 후반 여아 $(.98, .03)$ 는 7 세 전반과 유사하였다. 즉, PCC-R와 마찬 가지로 $\mathrm{PWC}$ 에서도 천정점수에 도달하는 시점이 평균적으로 여아가 6개월 정도 빠르다고 할 수 있다.

PMLU는 음운결합의 복잡성을 보여주는 지표로 초기 말소리 발달을 민감하게 반영하는 지표이다. PMLU에 대한 선행연구 를 살펴보면, Ingram \& Ingram(2001)은 PMLU의 중간값 3, 4, 5, $6,7,8$ 에 이르는 시기를 각각 말소리발달의 I, ㅍ, II, IV, V, VI 단계로 제안하였다. Yoon et al.(2013)에서는 우리나라 아동의 경우도 자발화에서 PMLU가 3세 전반 7.7, 3세 후반 이후 8로 증 가한다고 하였다. 동일한 아동들을 대상으로 한 Ha et al.(2019) 의 단어수준 연구에서는 PMLU가 3세 전반에서 7.6,3세 후반에 서 8 로 보고되었다. 본 연구 결과 3 세 전반 9.6, 3 세 후반 10 이상 으로 선행연구보다 전반적으로 높은 PMLU를 보였다. 이는 문 장 따라말하기 과제를 이용하였기 때문에 나타난 결과로, 미리 정해놓은 모방 문장의 음운적 복잡성이 선행연구(Ha et al., 2019)에서 사용한 단어 이름대기 과제의 목표어보다 높았다. 또 한 연구 결과 5세 후반에 PMLU 값이 천정점수에 도달하였으 며, 그 이후 연령집단은 유의한 차이를 보이지 않았다.

마지막으로 성인의 목표 PMLU에 근접한 정도를 분석하는 $\mathrm{PWP}$ 는 3 세 초반 평균 $.89,3$ 세 후반 평균 .93으로, 3세 후반에 천 정점수에 다다르는 것으로 나타났다. $\mathrm{PWP}$ 를 분석한 선행연구 를 살펴보면, 단어수준 연구인 Park \& Seok(2012), Park \& Son (2012), Kim \& Seok(2007), Ha et al.(2019)과 자발화 연구인 Yoon et al.(2013) 모두에서 3세 이후.90 이상으로 본 연구 결과와 일 치하였다. 따라서 일반아동의 경우 PWP는 문맥에 상관없이 음 운발달 초기에 천정점수에 도달하는 지표임을 알 수 있다.

정리하면, 본 연구는 다음의 두 가지 측면에서 그 의의를 찾 을 수 있다. 첫째, 한국어의 말소리 발달에 대해 신뢰할 수 있는 전국 규모의 자료를 제공하였다는 점이다. 동일한 아동들을 대 상으로 단어수준의 연구를 진행한 Ha et al.(2019)에서는 2세 후 반부터 7세까지의 말소리발달의 시기에 대해 1단계 말소리목 록 확장기(2세 후반 3세 전반), 2 단계 말소리 정교화기(3세 후 반 4세 후반), 3 단계 말소리 안정기(5세 전반 이후)로 구분하 여 매우 의미 있는 제안을 하였다. 그럼에도 불구하고 연구자들 은 해당 연구에 대해 단어수준에서 유도된 발화를 토대로 하였 다는 점을 그 제한점으로 언급하면서, 문장 혹은 자발화에 대해 유사한 연구가 실시될 필요가 있음을 덧붙였다. 이와 같은 필요 성에서 출발한 본 연구는 문장수준 발화에서 PCC-R, PWC, PMLU, PWP의 네 지표 모두 5세 후반에 들어서면 이후 연령집 단들과 유의한 차이를 보이지 않음을 밝혔다는 점에서 주목할 만하다. 이는 문장수준 발화에서도, 단어수준 발화와 크게 다르 지 않게, 5세 후반 이후에는 말소리발달이 안정기로 들어서고 있음을 시사한다.

두 번째 의의는 말소리장애 임상현장에서 문장 따라말하기 
과제로 평가를 실시할 때 비교 가능한 연령별 규준을 제공하였 다는 점이다. 문장 따라말하기는 말-언어발달 과정에서 나타나 는 문제들을 민감하게 검사해줄 수 있는 유용한 과제로 알려져 있다. 그럼에도 불구하고 비교할 만한 연령별 규준이 제공되지 않아 임상현장에서 활용하는 데에 한계가 있었다. 특히 본 연구 는 급격한 말소리발달이 이루어지는 학령전기의 특성을 고려 하여 6개월을 단위로 집단을 나누었고, 국내 전 지역에서 대상 자들을 모집하였다는 점에서 더욱 의의가 있다. 이로 인해 지역 에 상관없이 모든 임상현장에서 본 자료를 활용할 수 있을 것으 로 기대한다.

마지막으로 추후 연구에 대한 제언을 덧붙이자면, 문장수준 과제를 실시할 때 동반되는 여러 요인들이 말소리발달에 어떠 한 영향을 미치는지를 확인해볼 필요가 있을 것이다. 그 구체적 인 예로 후행 모음이 말소리산출 및 말소리발달에 미치는 영향 을 들 수 있다. 본 연구에서 사용된 자극문장은 전설모음과 후 설모음, 고설모음과 저설모음에서 모든 자음이 산출되도록 구 성되어 있다. Kang et al.(2019)은 3세 전반과 3세 후반을 나누어 모음문맥별 치경마찰음 $/ \mathrm{s} /, / \mathrm{s} * /$ 의 발달을 보았는데, 3 세 전반에 서 평음 $/ \mathrm{s} /$ 는 $/ \mathrm{u}, \mathrm{a} /$ 모음에서 가장 높은 정확도를 보인 반면, 경음 $/ \mathrm{s} * /$ 는 /i/모음 앞에서 가장 높은 정확도를 보였다. 이러한 연구 결과에 근거할 때, 치경마찰음 이외의 자음들도 후행 모음에 따 라 발달 양상이 다르게 나타날 가능성을 생각해볼 수 있다. 그 밖에 반복 산출 시 나타나는 변이성(혹은 비일관성), 형태소 종 류, 어휘 난이도, 어휘 빈도 등 말소리발달에 영향을 미칠 수 있 는 다양한 요인들을 생각해볼 수 있으며, 추후 연구들에서 이에 대한 궁금증이 하나씩 해결될 수 있기를 기대한다.

\section{References}

Bang, J. H. (2017). Determining severity of children with speech sound disorders (Master's thesis). Korean Nazarene University, Cheonan, Korea.

Choi, M. S., \& Kim, S. J. (2013). Morphological influences on liquid acquisition in Korean children's spontaneous speech. Communication Sciences and Disorders, 18(1), 76-85.

DuBois, E. M., \& Bernthal, J. E. (1978). A comparison of three methods for obtaining articulatory responses. Journal of Speech and Hearing Disorders, 43(3), 295-305.

Ha, J. W., Kim, S. J., Kim, Y. T., \& Shin, M. J. (2019). Developmental analysis in Korean children's speech production using percentage of consonants correct and whole-word measurements. Communication Sciences \& Disorders, 24(2), 469-477.

Ha, S., \& Hwang, J. (2013). Speech measures from phonological analyses of spontaneous conversations in children between 18 47 months of age. Communication Sciences \& Disorders, 18(4), 425-434.

Ingram, D. (2002). The measurement of whole-word productions. Journal of Child Language, 29(4), 713-733.
Ingram, D., \& Ingram, K. D. (2001). A whole-word approach to phonological analysis and intervention. Language, Speech, and Hearing Services in Schools, 32(4), 271-283.

Johnson, J. P., Winney, B. L., \& Pederson, O. T. (1980). Single word versus connected speech articulation testing. Language, Speech and Hearing Services in Schools, 11(3), 175-179.

Kang, R., Kim, D., Kim, H., Lee, M., Lee, J., \& Kim, S. (2019). Development of the sounds $/ \mathrm{s} /, / \mathrm{s} *$ for Korean 3-year-old children. Proceedings of 2019 Joint Conference of the Korean Academy of Speech-Language Pathology and Audiology and the Korean Speech-Language \& Hearing Association (pp. 269-270).

Kenny, K. W., Prather, E. M., Mooney, M. A., \& Jeruzal, N. C. (1984). Comparisons among three articulation sampling procedures with preschool children. Journal of Speech, Language, and Hearing Research, 27(2), 226-231.

Kim, M. J., Pae, S. Y., \& Lee, S. E. (2005). The development of the 'Test of Articulation for Children': Concurrent validity. Communication Science \& Disorders, 10(1), 82-96.

Kim, M. J., Pae, S. Y., \& Park, C. I. (2007). Assessment of phonology and articulation for children: APAC. Seoul, Korea: Human Brain Research and Consulting.

Kim, S. J. (2016). Developing the 3 sentence screening test for speech sound disorders and prevalence in 6-year-old children. Communication Sciences \& Disorders, 21(4), 580-589.

Kim, S. J., Jang, K. W., Hwang, D. H., \& Chang, M. S. (2016). Development of Korean speech sound analysis tool (KSAT). Proceedings of the 2016 Fall Conference of the Korean Society of Speech Sciences (KSSS) (pp. 121-122).

Kim, S. J • , Kim, J. M • , Yoon, M. S ·, Chang, M. S · , \& Cha, J. E. (2012). Alveolar fricative sound errors by the type of morpheme in the spontaneous speech of 3- and 4-year-old children. Phonetics and Speech Sciences, 4(3), 129-136.

Kim, S. J., \& Shin, J. Y. (2015). Speech sound disorders. Seoul, Korea: Sigmapress.

Kim, Y. E., \& Seok, D. I. (2007). Phonological characteristics of normal and functional articulation/phonological disorders children by measure of whole-word. Journal of Speech-Language \& Hearing Disorders, 16(3), 79-92.

Kim, Y. T., Hong, G. H., Kim, K. H., Jang, H. S., \& Lee, J. Y. (2009). Receptive \& Expressive Vocabulary Test (REVT). Seoul: Seoul Community Rehabilitation Center.

Kim, Y. T., \& Shin, M. J. (2004). Urimal Test of Articulation and Phonology (U-TAP). Seoul, Korea: Hakjisa.

Kim, Y. T., Shin, M. J., Kim, S. J., \& Ha, J. W. (2020). Urimal Test of Articulation and Phonology 2 (UTAP2). Seoul, Korea: Hakjisa.

Park, H., \& Seok, D. I. (2012). Phonological whole-word measures in children aged 2 to 4 years. Journal of Speech-Language and Hearing Disorders, 21(1), 53-70. 
Park, H., \& Son, E. N. (2012). A study of the phonological characteristics of preschool children by measures of whole-words. Journal of Speech \& Hearing Disorders, 21(4), 19-34.

Park, H. J., Hwang, H. J., \& Park, H. (2011). A study on phonological characteristics of two-years-old children by measures of wholeword. Journal of Speech-Language and Hearing Disorders, 20(1), 123-135.

Park, K., \& Kim, S. J. (2015). A comparison of phonological error patterns in the single word and spontaneous speech of children with speech sound disorders. Phonetics and Speech Sciences, 7(3), 165-173.

Park, E. H., \& Yoon, M. S. (2016). Speech sound development of toddlers in spontaneous speech: Segmental level and whole word level analysis. Korean Journal of Early Childhood Special Education, 16(2), 111-130.

Seok, D. I. (2006). A whole-word approach to phonological analysis with normal children aged from 3 to 5 years, Journal of Speech \& Hearing Disorders, 15(1), 15-28.

Seok, D. I., Park, S. H., Shin, H. J., \& Park, H. J. (2008). Korean Standard Picture of Articulation and Phonological Test (KS$P A P T)$. Seoul, Korea: Hakjisa.

Shin, M., Ha, J. W., Kim, Y. T., \& Kim, S. J. (2019). Regional differences in Korean children's development of speech production. Phonetics and Speech Sciences, 11(3), 57-67.

Shriberg, L. D., \& Kwiatkowski, J. (1982). Phonological disorders III: A procedure for assessing severity of involvement. Journal of Speech and Hearing Disorders, 47(3), 256-270.

Woo, H. K., \& Kim, S. J. (2013). Coda sounds acquisition at word medial position in three and four year old children's spontaneous speech. Phonetics and Speech Sciences, 5(3), 73-81.

Yoon, M. S., Kim, J. M., \& Kim, S. J. (2013). Phonological whole-word measures of spontaneous speech in children two to four years of age. Journal of Speech-Language \& Hearing Disorders, 22(4), 69-85.

\section{- 김수진 (Soo-Jin Kim)}

나사렛대학교 언어치료학과 교수

충청남도 천안시 서북구 쌍용 2 동 456 번지

Tel: 041-570-7978 Fax: 041-570-7846

Email: sjkim@kornu.ac.kr

관심분야: 말소리장애, 말소리발달

\section{- 박나래 (Na rae Park)}

나사렛대학교 일반대학원 언어치료전공 석사과정생

충청남도 천안시 서북구 쌍용 2 동 456 번지

Tel: 041-570-7978 Fax: 041-570-7846

Email: 201816002@slp.education
관심분야: 말소리장애, 말소리발달

- 장문수 (Moon-Soo Chang)

서경대학교 소프트웨어학과 교수

서울시 성북구 서경로 124

Tel: 02-940-7754

Email: cosmos@skuniv.ac.kr

관심분야: 인공지능, 언어이해

\section{- 김영태 (Young Tae Kim)}

이화여자대학교 언어병리학과 교수 서울특별시 서대문구 이화여대길 52

Tel: 02-3277-2120 Fax: 02-3277-2122

Email: youngtae@ewha.ac.kr 관심분야: 언어발달장애, 말소리장애

\section{- 신문자 (Moonja Shin)}

조선대학교 언어치료학과 교수

광주광역시 동구 필문대로 309

Tel: 062-230-6187 Fax: 062-230-6271

mail: moonjashin@chosun.ac.kr

관심분야: 유창성장애, 말소리장애

- 하지완 (Ji-Wan Ha) 교신저자

대구대학교 언어치료학과 교수

경상북도 경산시 진량읍 대구대로 201

Tel: 053-850-4327 Fax: 053-850-4329

Email: jw-ha@daegu.ac.kr

관심분야: 말소리장애, 신경말-언어장애

부록 1. 따라말하기 문장 과제

\begin{tabular}{c|l}
\hline & \multicolumn{1}{|c}{ 목표 문장 } \\
\hline 연습 & 땡 땡이와 씩씩이는 친구에요. \\
\hline 1 & 땡 땡이와 씩씩이는 놀러가기로 했어요. \\
\hline 2 & 자동차를 타고 동물원에 갔어요. \\
\hline 3 & 가족들과 코끼리차 맨 뒤에 앉았어요. \\
\hline 4 & 창밖으로 호랑이, 코뿔소가 보였어요. \\
\hline 5 & 커다란 돌고래가 춤추는 건 없어졌어요. \\
\hline 6 & 키 큰 공주님 옆에서 사진 찍었어요. \\
\hline 7 & 풀밭에 돗자리를 쭉 깔았어요. \\
\hline 8 & 비빔밥, 수박, 팝콘을 먹었어요. \\
\hline 9 & 햇빛이 쨍쨍 뜨거워서 땀이 났어요. \\
\hline 10 & 쓰레기는 봉투에 담아서 돌아왔어요. \\
\hline 11 & 참 신나는 하루였다. 끝. \\
\hline
\end{tabular}




\title{
문장 따라말하기 과제에서 3 7세 아동의 말소리발달
}

\author{
김 수 진 ${ }^{1} \cdot$ 박 나 래 ${ }^{1}$ 장 문 수 ${ }^{2} \cdot$ 김 영 태 ${ }^{3}$ 신 문 자 ${ }^{4} \cdot$ 하 지 완 \\ ${ }^{1}$ 나사렛대학교 언어치료학과, ${ }^{2}$ 서경대학교 소프트웨어학과, \\ ${ }^{3}$ 이화여자대학교 언어병리학과, ${ }^{4}$ 조선대학교 언어치료학과, ${ }^{5}$ 대구대학교 언어치료학과
}

\begin{abstract}
국문초록
아동이 산출하는 말소리를 평가할 때 단어와 문장을 유도하여 산출한 말소리를 분석하고, 자발화를 이용하여 분석 하기도 한다. 단어 검사와 자발화 검사의 한계를 보완할 수 있는 평가 방법으로 문장 따라말하기 과제가 있다. 문장 따라말하기 과제를 통한 아동의 말소리 평가는 자발화와 유사한 특성을 보이면서 단어와 같이 제한된 시간 안에 다양한 음소를 평가할 수 있다. 본 연구에서는 다양한 모음문맥에서 자음을 배치하고 모든 음소가 3 회 이상의 출현 기회를 가질 수 있도록 계획된 11 개의 문장 따라말하기를 통해 연령과 성별에 따라서 단어단위 음운지표와 개정자 음정확도의 발달을 살펴보았다. 전국에 거주하는 3세부터 7세까지 아동 535명을 대상으로 UTAP2에 새롭게 포함 된 11 개 문장 따라말하기 과제를 실시하였다. 말소리발달을 평가할 수 있는 지표 PCC-R, PWC, PMLU, PWP을 구하 였다. 아동은 연령별 6 개월 단위로 10 개의 집단을 구분하고 각 지표에 대해 연령집단과 성별에 따른 차이를 분석하 였다. 연구 결과, 모든 지표에서 연령이 증가함에 따라 수치가 상승하였으며 연령집단 간 차이는 유의하였다. 성별 에 따른 차이와 연령과 성별의 상호작용효과는 유의하지 않은 것으로 나타났다. 본 연구는 전국에서 자료를 수집 하였고, 연령집단을 6 개월로 나누어 보았으며, 집단별 데이터를 충분히 수집하였다는 점과 단어와 자발화 검사의 한계점을 보완할 수 있는 문장 따라말하기라는 새로운 말소리 평가 방법의 연령별 준거 자료를 제시하였다는 측면 에서 의의가 있다.
\end{abstract}

핵심어: 말소리장애, 문장 따라말하기, 단어단위 음운지표, 말소리발달

\section{참고문헌}

강리지, 김다현, 김효진, 이민지, 이지은, 김수진(2019). 모음문맥 에 따른 3세 전반과 후반의 치경마찰음 / ㅅ//, / ㅆ / 수행력 발달 비교. 2019 한국언어청각임상학회, 언어치료학회 공동학술대 회 자료집, 269-270.

김민정, 배소영, 이성은(2005). 아동용 조음검사의 개발: 공인타 당도 검증. 언어청각장애연구, $10(1), 82-96$.

김민정, 배소영, 박창일 (2007). 아동용 발음평가 $A P A C)$. 서울: 휴 브알앤씨.

김영은, 석동일 (2007). 단어 단위 측정에 의한 정상 아동과 기능 적 조음음운장애 아동 간 음운 특성 비교. 언어치료연구, $16(3)$, 79-92.

김영태, 신문자 (2004). 우리말 조음 - 음운평가 (U-TAP). 서울: 학 지사.

김영태, 신문자, 김수진, 하지완 (2020). 우리말조음음운검사 2(UTAP2). 서울: 학지사.

김영태, 홍경훈, 김경희, 장혜성, 이주연(2009). 수용표현어휘력 검사 $(R E V T)$. 서울: 서울장애인종합복지관.

김수진 (2016). 말소리장애 선별검사 개발 및 6세 아동의 출현율
조사. 언어청각장애연구, 21(4), 580-589.

김수진, 김정미, 윤미선, 장문수, 차재은 (2012). 자발화에 나타난 형태소 유형에 따른 3 4세 아동의 치경마찰음 오류. 말소리 와 음성과학, 4(3), 129-136.

김수진, 장기완, 황득하, 장문수 (2016). 한국어말소리평가프로 그램(Korean Speech Sound Analysis Tool: KSAT) 개발. 한국음 성학회 가을 학술대회 발표논문집(pp. 121-122).

김수진, 신지영 (2015). 말소리장애. 서울: 시그마프레스. 박가연, 김수진 (2015). 말소리장애 아동의 단어와 자발화 문맥 의 음운오류패턴 비교. 말소리와 음성과학, 7(3), 165-173.

박현, 석동일 (2012). 단어단위 분석에 의한 2 4세 유아의 조음 음운 특성 연구. 언어치료연구, 21(1), 53-70.

박현, 손은남 (2012). 단어단위 음운 분석을 통한 취학전 아동들 의 음운 특성 연구. 언어치료연구, 21(4), 19-34.

박은희, 윤미선(2016). 자발화에 나타난 2 3세 유아의 말소리발 달: 분절음과 단어 단위에서의 평가. 유아특수교육연구, 16(2), 111-130.

박희정, 황하정, 박현 (2011). 단어단위 음운분석을 통한 2 세 유아 의 음운 특성연구. 언어치료연구, 20(1), 123-135.

방진희 (2017). 말소리장애 아동의 심각도 평정. 나사렛대학교 석 
사학위논문.

석동일 (2006). 단어단위 접근법에 의한 3 5세 유아의 음운특성 분석. 언어치료연구, 15(1), 15-28.

석동일, 박상희, 신혜정, 박희정 (2008). 한국어 표준 그림 조음음 운검사 $(K S-P A P T)$. 서울: 학지사.

신문자, 하지완, 김영태, 김수진 (2019). 우리나라 아동의 지역별 말소리 발달 차이. 말소리와 음성과학, 11(3), 57-67.

우혜경, 김수진 (2013). 자발화에 나타난 3 4세 아동의 어중종성 습득. 말소리와 음성과학, 5(3), 73-81.

윤미선, 김정미, 김수진 (2013). 자발화 문맥에서의 단어단위 음 운 평가: 2 4세 아동. 언어치료연구, 22(4), 69-85.

최민실, 김수진 (2013). 자발화에 나타난 3 4세 아동의 형태소 유형별 유음 발달 특성. 언어청각장애연구, 18(1), 76-85.

하승희, 황진경 (2013). 18-47개월 아동의 자발화 분석에 기초한 말소리 측정치에 관한 연구. 언어청각장애연구, 18(4), 425-434.

하지완, 김수진,김영태, 신문자 (2019). 자음정확도와 단어단위 음운지표를 이용한 일반아동의 말소리 산출능력에 대한 발달 연구. 언어청각장애연구, 24(2), 469-477. 